Original Research Paper

\title{
Karakterisasi Morfologi Tanaman Pisang di Daerah Lombok
}

\author{
Rina Kurnianingsih $^{1^{*}}$, Sri Puji Astuti ${ }^{1}$, Mursal Ghazali ${ }^{1}$ \\ ${ }^{1}$ Program Studi Biologi FMIPA Universitas Mataram
}

\section{Article history}

Received: 13 September 2018

Revised: 6 November 2018

Accepted: 11 Desember 2018

Published: 15 Desember 2018

*Corresponding Author:

Rina Kurnianingsih, Program

Studi Biologi FMIPA

Universitas Mataram

Email:

rkurnianingsih@unram.ac.id

\section{Pendahuluan}

Pulau Lombok merupakan salah satu pulau yang terletak di gugusan pulau sunda kecil. Selain itu, secara biogeografi pulau lombok terletak diantara garis wallacea di bagian barat dan webber dibagian timur. Kenyataan ini membuat pulau-pulau yang berada di biogeografi ini kaya akan flora dan fauna endemik, termasuk pulau lombok. Kekayaan plasma nutfah dapat dimanfaatkan untuk memenuhi kebutuhan pangan, sebagai sumberdaya hayati dan sumber gen untuk pemuliaan tanaman. Namun, kekayaan flora dan fauna ini terus mengalami penurunan setiap tahunnya. Selain disebabkan oleh penurunan luas lahan (alih fungsi lahan), penurunan juga disebabkan oleh minat masyarakat terhadap produk lokal semakin menurun dan diikuti oleh masuknya produk dari luar. Oleh karena itu, diperlukan upaya pelestarian dan pengembangan plasma nutfah untuk mempertahankan keanekargaman hayati.

Pisang merupakan salah satu plasma nutfah yang tersebar luas di wilayah Indonesia. Tanaman pisang (Musa sp) terbagi kedalam dua kelompok, yaitu pisang berbiji (liar) dan pisang yang dapat di konsumsi (Valmayor et al., 2002). Indonesia merupakan asal dan pusat keanekaragaman pisang baik tipe liar dan kultivar (Daniells et al., 2001; Hapsari, 2015). Menurut Valmayor et al. (2002) kurang lebih 54 kultivar pisang ditemukan di Indonesia.

Musa acuminata (AA) dan Musa balbisiana (BB) merupakan jenis pisang yang menjadi tetua, selanjutnya dari kedua jenis pisang ini muncul berbagai variasi genetik (Wahyuningtias et al., 2009). Dalam proses evolusi, sifat liar yang dicirikan dengan fertilitas bunga yang tinggi dan dapat membentuk biji mengalami perubahan dan tanaman kehilangan sebagian bahkan seluruh sifat ini. Hal ini terjadi baik pada kepala sari maupun pada bakal biji, sehingga semua pisang budidaya bersifat steril dan tidak berbiji (Megia, 2005).

Keragaman plasma nutfah pisang lokal di Pulau Lombok cukup besar dengan ciri morfologi yang beragam. Pada dasarnya pisang lokal memiliki sifat unggul yang diturunkan, misalnya ketahanan terhadap iklim, ketahanan terhadap hama penyakit, serta rasa yang khas. Untuk itu, pisang lokal harus dikelola dengan baik 
untuk dimanfaatkan secara maksimal, salah satunya ialah sebagai sumber keragaman genetik untuk perbaikan varietas tanaman pisang. Di Pulau Lombok ditemukan beragam kultivar pisang dengan keunggulan masingmasing. BPPT NTB telah mengoleksi 15 kultivar pisang yang dibudidayakan di Pulau Lombok. Kultivar pisang yang dikoleksi ialah pisang haji, candi, kayu, ketip, jepun, emas, tembaga, jogang, klutuk, seribu, tanpa jantung, raja dan susu burik (Rahayu dan Fitrahtunnisa, 2014). Studi keragaman pisang lokal Lombok perlu dilakukan karena sejauh ini informasi tersebut belum tersedia.

\section{Bahan dan Metode}

Penelitian ini bersifat eksploratif dengan mengidentifikasi secara langsung ke lapangan kultivar tanaman pisang yang dibudidayakan menggunakan metode jelajah. Bahan yang digunakan adalah tanaman pisang, sedangkan alat yang digunakan adalah alat tulis, gunting, plastik, label nama, kain hitam, meteran dan kamera digital.

Karakterisasi morfologi batang dan daun dilaksanakan berdasarkan pengamatan terhadap ketegakan daun, warna tepi pelepah daun, keadaan tepi pelepah daun, bentuk pangkal daun, tipe kanal, bercak pada pangkal pelepah daun, warna bercak pelepah, warna permukaan atas daun dan warna permukaan bawah daun, sedangkan karakterisasi bunga meliputi warna dasar compound tepal, pigmentasi compound tepal, warna free tepal, warna filamen, warna anther, bentuk style, warna stigma, bentuk ovary, warna dasar ovary, dan warna dominan dari bunga (Ambarita et al., 2015; IPGRI-INIBAP/CIRAD, 1996).

\section{Hasil dan Pembahasan}

Tanaman pisang merupakan salah satu tanaman hortikultura yang banyak dibudidayakan didaerah Lombok, namun sampai saat ini belum terdapat informasi mengenai karakteristik morfologi kultivar pisang lokal Pulau Lombok. Untuk menentukan kultivar pisang lokal Lombok dihadapkan pada kendala berupa penamaan kultivar pisang pada lokasi/daerah yang berbeda-beda. Beberapa kultivar pisang yang sama memiliki nama yang berbeda pada lokasi/daerah yang berbeda, misalkan pisang Kelak (daerah Suela-Lombok Timur), didaerah Sambelia diberi nama pisang Sambelia atau pisang Haji.

Pada penelitian ini, diperoleh 19 kultivar pisang, karakterisasi morfologi batang semu, daun, dan bunga menunjukkan variasi. Terdapat variasi pada warna batang semu dan warna bercak pada batang semu dari kultivar pisang yang dibudidayakan di daerah Lombok (Tabel1).

Tabel 1. Karakterisasi Morfologi Batang Kultivar Pisang

\begin{tabular}{cccc}
\hline No & Kultivar & Warna Batang Semu & $\begin{array}{c}\text { Warna Bercak pada } \\
\text { Batang Semu }\end{array}$ \\
\hline 1 & Ijo & Hijau-Merah & Coklat kehitaman \\
2 & Kayu & Merah kehijaun & Coklat \\
3 & & Kuning kehijauan & Coklat kehitaman \\
& Ketip & Merah & Coklat kehitaman \\
4 & Kelak & Merah kehijauan & Coklat \\
5 & Kombol & Hijau & Coklat kehitaman \\
6 & Lilin & Kuning kehijauan & Coklat kehitaman \\
7 & Lomak 1 & Kuning kehijauan & Hitam \\
8 & Lomak 2 & Merah kehijauan & Coklat \\
9 & Mas Jamak & Merah & Coklat kehitaman \\
10 & Mas Jogang & Merah & Coklat kehitaman \\
11 & Tembaga & Hijau & Coklat kehitaman \\
12 & Raja & Hijau & Coklat \\
13 & Sabe & Hijau & Hitam \\
14 & Batu & Kuning & Coklat \\
15 & Belendang & Merah & Hitam \\
16 & Bulan & Merah & Coklat \\
17 & Lawe & Merah & Coklat \\
18 & Susu & Kuning kehijauan & Coklat \\
19 & Susu Burik & & \\
\hline
\end{tabular}


Warna batang semu kultivar pisang diantaranya hijau-merah (kultivar Ijo), merah kehijauan (kultivar Kayu, Kombol, Mas Jamak), kuning kehijauan (Ketip, Lomak, Susu Burik), merah (kultivar Kelak, Mas Jogang, Tembaga, Bulan, Lawe, Susu), dan berwarna hijau (kultivar Lilin, Raja, Sabe) (Gambar 1). Kultivar pisang yang memiliki warna batang semu merah disebabkan karena menghasilkan pigmen antosianin. Perbedaan warna pada batang semu diduga disebabkan karena perbedaan kandungan antosianin pada masingmasing kultivar pisang (Karamura, 1998). Menurut Rahmawati dan Hayati (2013), warna batang semu dasar dominan hijau memiliki kecenderungan pada sifat dari Musa balbisiana (Genom B) dan warna selain itu membawa sifat dari Musa acuminata (Genom A).

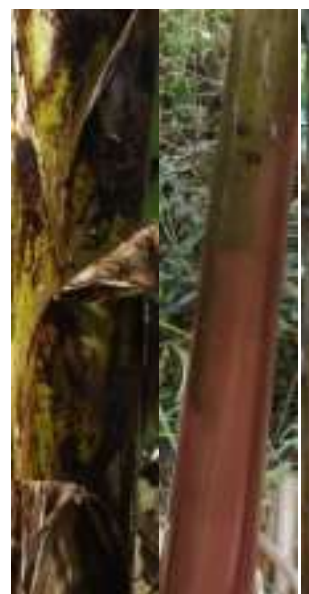

A

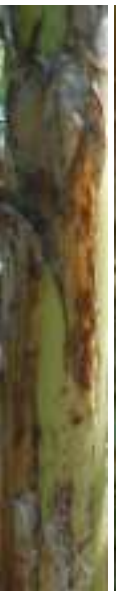

C

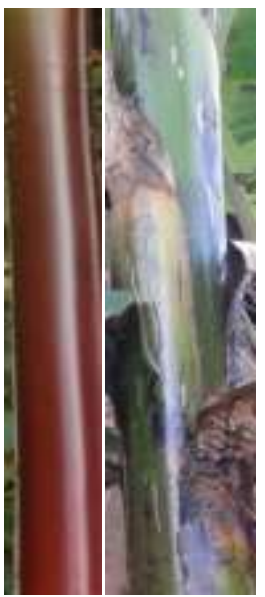

$\mathrm{E}$
Gambar 1. Warna pada batang semu pada kultivar pisang : A (hijau-merah), B (merah kehijauan), C (kuning kehijauan), D (merah), dan E (Hijau)

Karakteristik lainnya yang diamati pada batang semu adalah warna bercak, dimana terdapat warna bercak yang bervariasi pada kultivar pisang. Sebagian besar bercak pada batang semu berwarna coklat kehitaman dan coklat, sedangkan 2 kultivar yaitu Lomak dan Bulan memiliki bercak berwarna hitam (Gambar 2). Ukuran bercak pada batang semu terdiri dari bercak besar dan padat, serta pada beberapa kultivar terdapat sedikit atau tanpa bercak. Pisang yang memiliki bercak besar dan padat cenderung memiliki sifat dari $M$. acuminata, sedangkan tanpa atau sedikit bercak cenderung memiliki sifat dari M. balbisiana (Rahmawati dan Hayati, 2013).

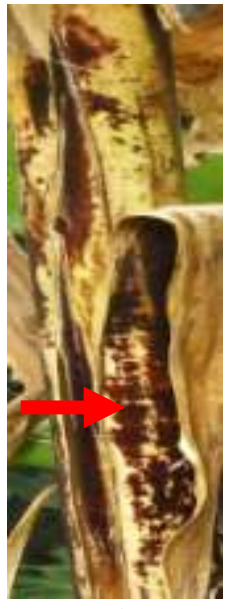

A

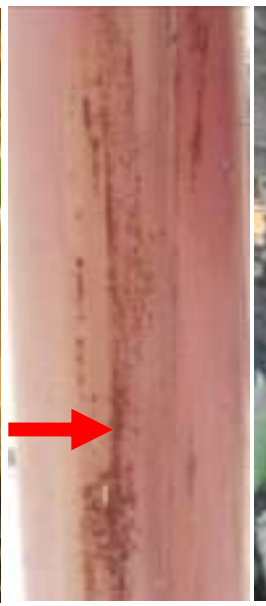

B

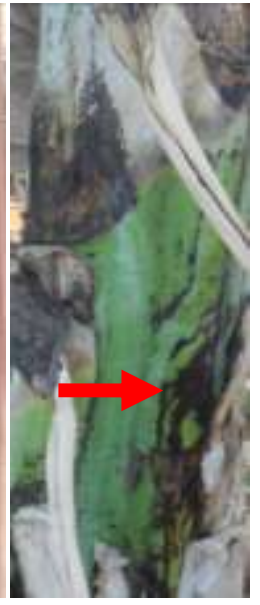

C
Gambar 2. Warna bercak pada batang semu kultivar pisang : A (coklat kehitaman), B (merah) dan C (hitam).

Karakteristik morfologi pada organ daun meliputi ketegakan daun, warna tepi pelepah daun, keadaan tepi pelepah daun, bentuk pangkal daun, tipe kanal, bercak pada pangkal pelepah daun, warna bercak pelepah, warna permukaan atas daun dan warna permukaan bawah daun. Ketegakan daun dari kultivar pisang meliputi tegak (kultivar Ijo, Kayu, Kelak, Kombol, Mas Jamak, dan Lawe), tipe intermediet/menengah pada kultivar Ketip, Lilin, Lomak, Raja, Sabe, Batu, Belendang, Susu, Susu Burik), sedangkan tipe melengkung ke bawah pada kultivar Mas Jogang, dan Bulan. Hal ini sesuai dengan hasil penelitian Khasanah dan Marsusi (2014), serta Nedha et al., (2017), yang menyatakan bahwa terdapat tiga macam tipe ketegakan daun yaitu tegak, intermediet/menengah dan melengkung.

Karakter keadaan tepi pelepah daun untuk semua kultivar sama, yaitu bersayap tidak menjepit batang (Gambar 3), sedangkan pada bentuk pangkal daun terdapat 3 variasi, yaitu runcing di dua sisi (kultivar Ijo, Lilin, Mas Jamak, Tembaga, Susu, Susu Burik), membulat pada satu sisi (kultivar Kayu, Ketip, Kombol, Lomak, Mas Jogang, Raja, Belendang, Bulan dan Lawe), dan membulat pada kedua sisi (Kultivar Kelak, Sabe, dan Batu) (Gambar 4). Hal ini sesuai dengan penelitian Herwitarahman dan Sobir (2014) bahwa terdapat 3 variasi bentuk pangkal daun, yaitu kedua sisi meruncing, kedua sisi melengkung/membulat dan salah satu sisi melengkung dengan sisi lain meruncing.

Bercak pangkal daun pada sebagian besar kultivar berupa bercak besar dan bercak kecil, kecuali pada kultivar kelak dan sabe tidak memiliki bercak pada pangkal daun. Warna bercak pada pangkal daun bervariasi yaitu coklat kehitaman, coklat dan hitam. 
Karakteristik warna pada permukaan atas dan bawah daun bervariasi yaitu hijau, hijau sedang, dan hijau kekuningan.

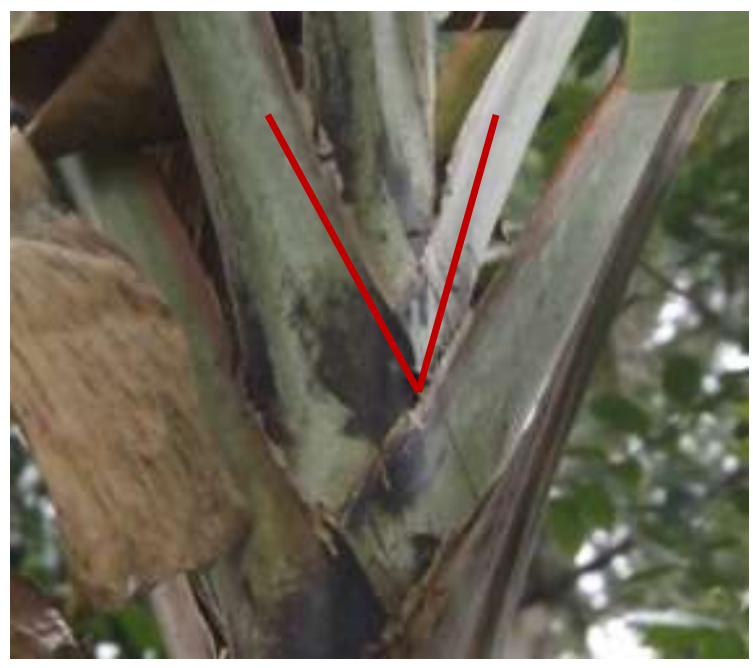

Gambar 3. Keadaan tepi pelepah daun : bersayap tidak menjepit batang
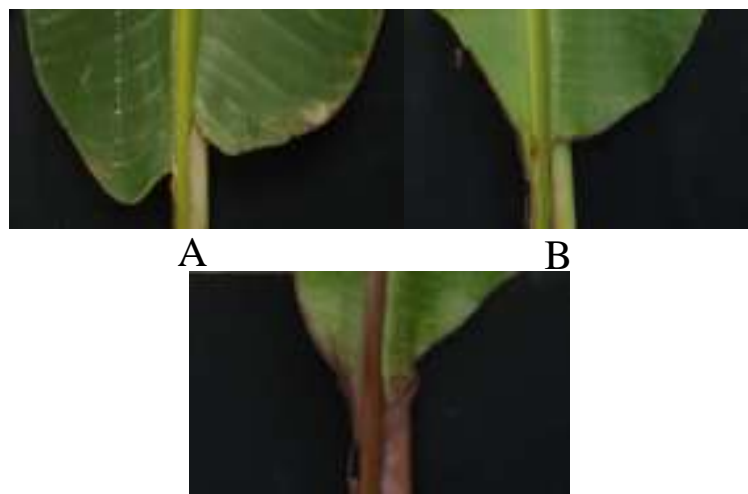

C

Gambar 4. Bentuk pangkal daun : A (dua sisi membulat), B (satu sisi membulat), dan C (dua sisi runcing)

Pada karakteristik tipe kanal terdapat 4 variasi, yaitu terbuka dengan tepi melebar ke samping, terbuka dengan tepi yang tegak, lurus dengan tepi tegak dan tepi tertutup (Gambar 5). Menurut Rahmawati dan Hayati (2013), pisang yang memiliki tipe lekuk kanal petiol terbuka dengan tepi berombak, tepi lebar tegak dan lurus dengan tepi tegak adalah pisang yang cenderung memiliki sifat dari M. acuminata (genom A). Sedangkan pisang yang memiliki tipe lekuk kanal petiol tepi melengkung kedalam cenderung memiliki sifat dari M. balbisiana (genom B).

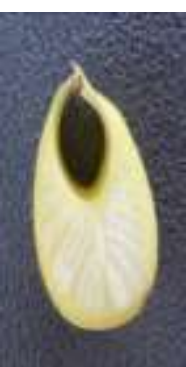

A

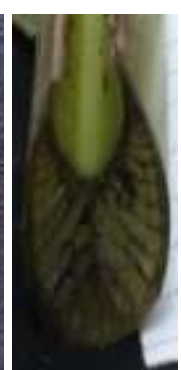

B

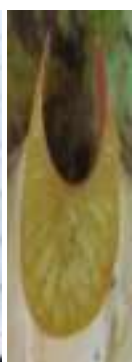

C

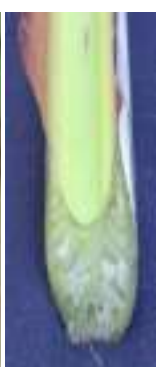

$\mathrm{D}$
Gambar 5. Bentuk kanal daun : A (tepi menutup), B (lurus dengan tepi tegak), dan C (terbuka dengan tepi tegak), dan D (terbuka dengan tepi yang melebar kesamping)

Karakteristik morfologi organ generatif diamati pada organ bunga. Berdasarkan hasil pengamatan, terdapat variasi pada sebagian besar karakteristik morfologi yang diamati, yaitu warna dasar compound tepal : krem dan kuning (Gambar 6). Karakteristik pigmentasi compound tepal meliputi sangat sedikit/tidak ada pigmentasi, pigmentasi berwarna merah muda, dan terdapat pigmentasi bintik-bintik berwarna seperti karat (Gambar 7).
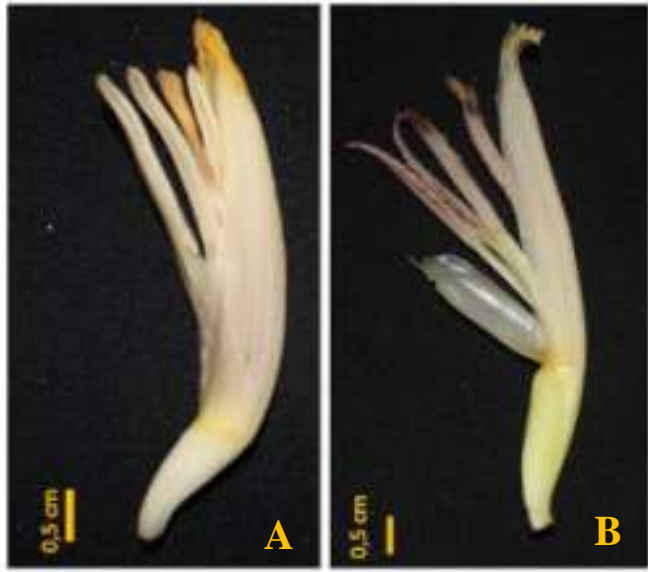

Gambar 6. Warna dasar compound tepal : A (krem), dan B (kuning)
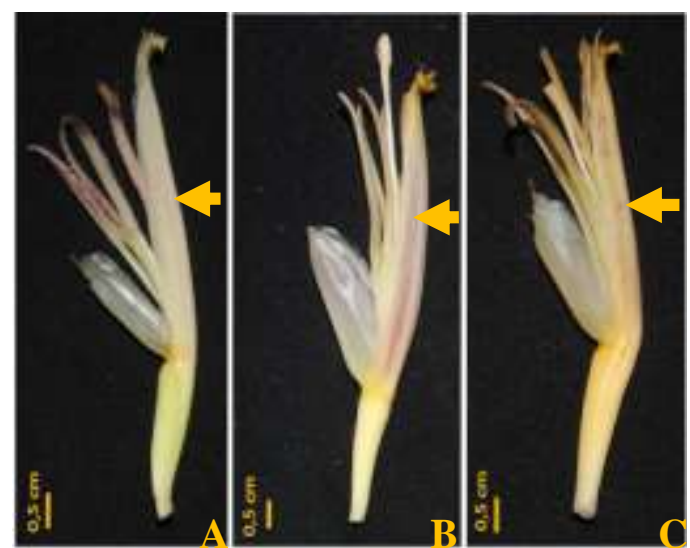

Gambar 7. Pigmentasi compound tepal : A (sangat sedikit/tidak ada pigmentasi), B (pigmentasi berwarna merah muda), dan C (pigmentasi bintik-bintik berwarna karat) 
Karakteristik warna free tepal pada kultivar pisang meliputi putih transparan, putih buram, terdapat semburat berwarna merah muda-ungu, dan semburat berwarna kuning (Gambar 8). Karakteristik bentuk style : lurus dan tipe bergelombang pada bagian dasar (Gambar 9).
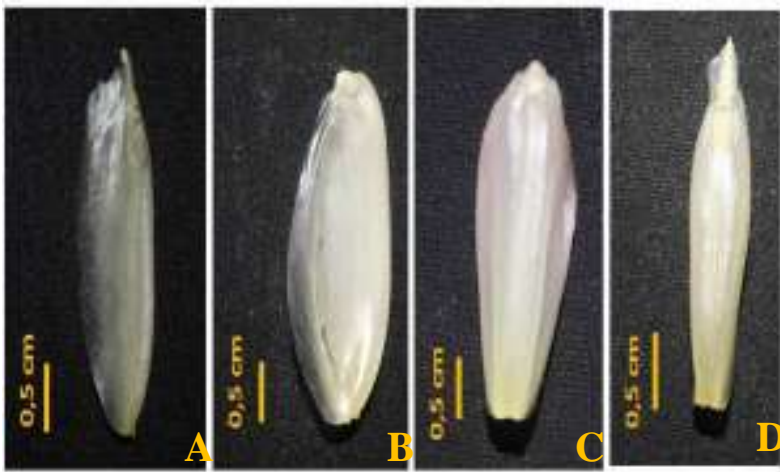

Gambar 8. Warna free tepal : A (putih transparan), B (putih buram), $\mathrm{C}$ (semburat berwarna merah muda-ungu), dan D (semburat berwarna kuning)
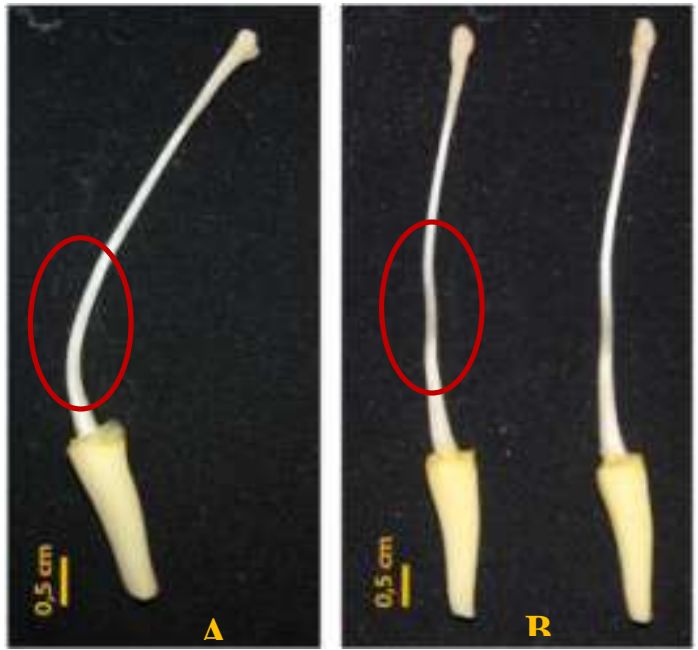

Gambar 9. Bentuk style : A (lurus), dan B (bergelombang pada bagian dasar)

Pada karakteristik warna stigma terdapat tiga variasi yaitu kuning, krem, dan kecoklatan (Gambar 10), bentuk ovary : tipe lurus dan melengkung (Gambar 11), warna dasar ovary, dan warna dominan dari bunga. Khusus untuk karakteristik free tepal, hanya kultivar Ketip yang tidak memiliki free tepal. Semua kultivar memiliki kesamaan pada ukuran bractea : x/y > 0,3, warna lobe pada compound tepal : kuning, dan sangat sedikit/tidak ada pigmentasi pada ovary.
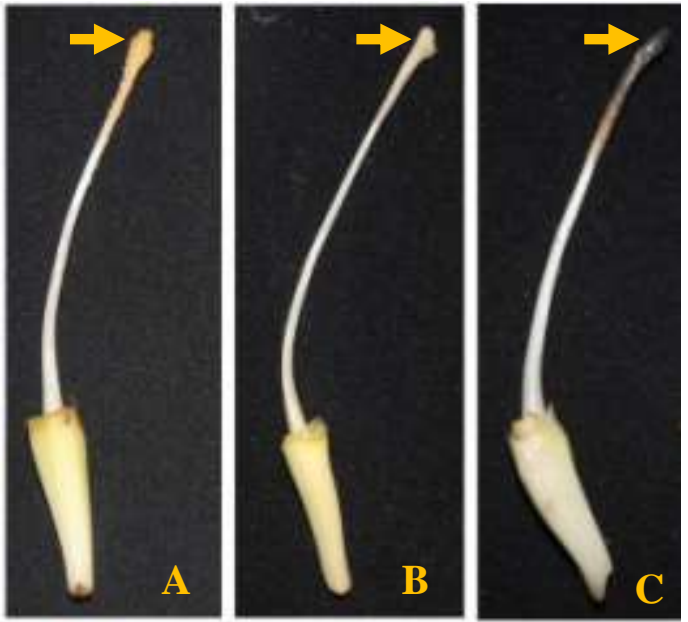

Gambar 10. Warna stigma : A (kuning), B (krem), dan C (kecoklatan)
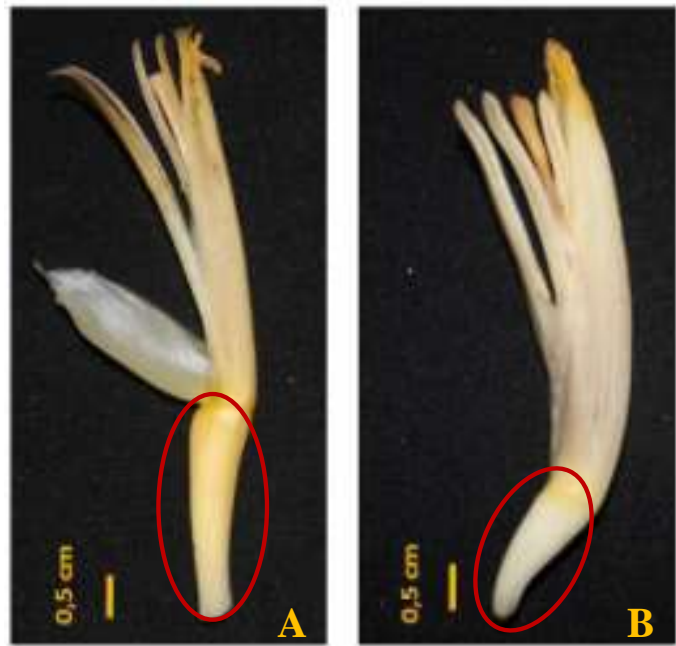

Gambar 11. Bentuk ovary : A (lurus), dan B (melengkung)

Perbedaan karakter morfologi yang terdapat pada setiap kultivar pisang dipengaruhi oleh banyak faktor, baik faktor genetik maupun lingkungan (Hiariej dan Karuwal, 2015). Populasi kultivar pisang yang terpisah akan memiliki kondisi lingkungan yang berbeda seperti suhu, kelembaban, curah hujan, $\mathrm{pH}$ tanah, tekstur tanah. Herwitarahman dan Sobir (2014) menyatakan bahwa adanya perbedaan kekhasan karakter antara kultivar pisang dapat dinyatakan sebagai kategori unik.

\section{Kesimpulan}

Berdasarkan hasil dan pembahasan dapat disimpulkan bahwa karakteristik morfologi tanaman pisang pada batang, daun, dan bunga bervariasi, kecuali pada karakter keadaan tepi pelepah daun, ukuran bractea, warna lobe pada compound tepal. Semua 
kultivar pisang memiliki keadaan tepi pelepah daun yang bersayap dan tidak menjepit batang, ukuran bractea : x/y $>0,3$, dan warna lobe pada compound tepal dari semua kultivar adalah kuning. Khusus untuk karakteristik free tepal, hanya kultivar Ketip yang tidak memiliki free tepal.

\section{Daftar Pustaka}

Ambarita, M.D.Y., Bayu, E.S. \& Setiado, H. (2015). Identifikasi Karakter Morfologis Pisang (Musa spp.) di Kabupaten Deli Serdang. Jurnal Agroekoteknologi. 4(1): 1911-1924.

Daniells, J., Karamura, D., Jenny, C., Lescot \& Tomekpe, K. (2001). Musalogue: A Catalogue of Musa Germplasm, Diversity in the Genus Musa. Montpellier. INIBAP., 207pp.

Hapsari, L. (2015). Genome Identification of Bananas (Musa L.) from East Java Indonesia Assessed with PCR-RFLP of The Internal Transcribed Spacer Nuclear Ribosomal DNA. International Journal of Biosciences. 7(3): 42-52.

Herwitarahman, A. \& Sobir. (2014). Simulasi Uji Baru Unik Seragam dan Stabil (BUSS) Pisang (Musa spp.) di Kebun Percobaan Pasir Kuda, Bogor. Bul. Agrohorti. 2(1) : 66-74.

Hiariej, A. \& Karuwal, R.L. (2015). Profil Lingkungan Tumbuh Pisang Tongkat Langit (Musa troglodytarum L.) di Kabupaten Maluku Tengah. BioWallacea Jurnal Ilmiah Ilmu Biologi. 1(1) : 59-63.

IPGRI-INIBAP/CIRAD. (1996). Descriptor for Banana (Musa paradisiaca L.). Diakses dari https.//www.inibap.org.

Karamura, D.A. (1998). Numerical Taxonomic Studies of the East African Highland Bananas (Musa AAA-East Africa) in Uganda (Ph.D. Dissertation). The University of Reading. England.

Khasanah, A.N. \& Marsusi. (2014). Karakterisasi 20 Kultivar Pisang Buah Domestik (Musa paradisiaca) dari Banyuwangi Jawa Timur. Jurnal El-Vivo. 2(1) : 20-27.

Megia, R. (2005). Musa sebagai Model Genom. Hayati. 12(4) : 167-170.
Nedha, Purnamaningsih, S.L. \& Damanhuri. (2017). Observasi dan Karakterisasi Morfologi Tanaman Pisang (Musa spp.) di Kecamatan Ngancar Kabupaten Kediri. Jurnal Produksi Tanaman. 5(5) : 821-827.

Rahayu, M. \& Fitrahtunnisa (2014). Kebun Koleksi Sumber Daya Genetik di BPTP NTB. Diakses dari https.//www.ntb.litbang.pertanian.go.id.

Rahmawati, M. \& Hayati, E. (2013). Pengelompokan Berdasarkan Karakter Morfologi Vegetatif pada Plasma Nutfah Pisang Asal Kabupaten Aceh Besar. Jurnal Agrista. 17(3) : 111-118.

Valmayor, R.V., Jamaluddin, S.H., Silayoi, B., Danh, L.D., Pascua, O.C. \& Espino, R.R.C. (2002). Banana Cultivar Names And Synonyms In Southeast Asia. Los Banos. INIBAP., 28pp.

Wahyuningtyas, W., Retnoningsih, A. \& Rahayu, E.S.. (2009). Keanekaragaman Genetika Pisang Bergenom B Berdasarkan Penanda Mikrosatelit. Biosaintifika. 1(1) : 1-10. 